Bangladesh J. Pl. Breed. Genet., 20(2) : 31-36, 2007

\title{
GENE ACTION OF AGRONOMIC TRAITS IN RICE (Oryza sativa L.)
}

\author{
P. S. Biswas and M. Enamul Haque \\ Plant Breeding Division \\ Bangladesh Rice Research Institute \\ Gazipur-1701, Bangladesh
}

\begin{abstract}
Six parent diallel cross without reciprocal was studied to investigate the genetic behavior of different agronomic traits in rice. The analysis of $\mathrm{Wr}-\mathrm{Vr}$ graph showed that panicle length, thousand grain weight and grain yield per plant did not follow the additivedominance model indicating epistatic gene action responsible for the expression of these traits. All other traits under the study were conditioned by overdominance gene action except grains per panicle, which was controlled by partial dominance. The $\mathrm{Yr}^{\prime}-(\mathrm{Vr}+$ $\mathrm{Wr})^{\prime}$ graph revealed random distribution of dominant and recessive gene in expressing different traits in different parent, while correlation between parental mean and parental order of dominance indicated increasing effect of dominant gene for all the traits except days to heading and $\%$ spikelet sterility.
\end{abstract}

Key words: Rice (Oryza sativa $\mathrm{L}$ ), $\mathrm{Vr}-\mathrm{Wr}$, gene action, agronomic traits, yield.

\section{INTRODUCTION}

Since the green revolution of 1960 s semi-dwarf rice varieties are mostly cultivated elsewhere in the world and the yield of such varieties has arrived at plateau. To ensure food security to the poor people in the developing countries, the productivity of rice must be increased in unit area. Exploitation of hybrid vigor, development of new plant type, introgression of foreign genes related to biotic and abiotic stresses may be some of the alternatives to have a breakthrough in this regard. Improvement of rice variety through the above techniques requires perfect knowledge of genetic background of the economic traits in rice plant. Therefore, an attempt has been undertaken to investigate the genetic behavior of different agronomic traits in rice.

\section{MATERIALS AND METHODS}

A $6 \times 6$ diallel (without reciprocal) cross was made using six advanced breeding

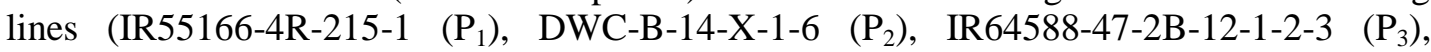
IR11141-6-R-1-4 $\left(\mathrm{P}_{4}\right)$, IR60436-B-65-2 $\left(\mathrm{P}_{5}\right)$ and BR683-65-4-1-1 $\left(\mathrm{P}_{6}\right)$ ). Fifteen $\mathrm{F}_{1}$ hybrids along with their parents were grown following randomized complete block design with two replications in the net house of Bangladesh Rice Research Institute in T. Aman 2004. The unit plot size was $2.5 \mathrm{~m} \times 2$ rows. Thirty days old single seedling was transplanted with a spacing of $20 \times 15 \mathrm{~cm}$. Data from each entry on different agronomic traits viz., days to heading, plant height $(\mathrm{cm})$, leaf area index, panicles per plant, filled grains per panicle, $\%$ spikelet sterility, 1000 grain weight $(\mathrm{g})$ and grain yield per plant $(\mathrm{g})$ were collected from 10 randomly selected plants. The collected data were analysed following graphical approach of Hayman (1954). Standardized values were calculated as suggested by Johnson and Askel 
(1959). The interpretations was made as per Dhabolkar (1992), Sharma (1998) and Mather and Jinks (1949).

\section{RESULTS AND DISCUSSION}

The analysis of variance revealed significant variations among the entries for all the traits under study (Table 1). The analysis of all arrays for $\mathrm{Wr}-\mathrm{Vr}$ graph showed that regression coefficients did not differ significantly from unity except days to heading and panicles per plant. But exclusion of array(s) satisfied the simple additive-dominance model for days to heading and panicles per plant (Table 2). Panicle length, thousand grain weight and yield per plant did not satisfy the simple additive-dominance model even after excluding one or more array(s). This indicated that thousand grain weight and grain yield per plant might be conditioned by epistatic gene action. Iftekharuddaula (2003) also observed similar finding in grain yield of rice.

Table 1. Analysis of variance in $6 \times 6$ diallel for ten characters in rice

\begin{tabular}{l|c|c|c|c|c|c|c|c|c|c|c}
\hline $\begin{array}{l}\text { Source of } \\
\text { variation }\end{array}$ & df & $\begin{array}{c}\text { Days to } \\
\text { heading }\end{array}$ & $\begin{array}{c}\text { Plant } \\
\text { height }\end{array}$ & $\begin{array}{c}\text { Flag leaf } \\
\text { area }\end{array}$ & $\begin{array}{c}\text { Leaf area } \\
\text { index }\end{array}$ & $\begin{array}{c}\text { Panicles/ } \\
\text { plant }\end{array}$ & $\begin{array}{c}\text { Panicle } \\
\text { length }\end{array}$ & $\begin{array}{c}\text { Filled grain/ } \\
\text { panicle }\end{array}$ & $\begin{array}{c}\% \text { spikelet } \\
\text { sterility }\end{array}$ & $\begin{array}{c}1000 \text { grain } \\
\text { weight }\end{array}$ & $\begin{array}{c}\text { Yield/ } \\
\text { plant }\end{array}$ \\
\hline Replication & 1 & 0.381 & 71.188 & 20.22 & 5.13 & 0.086 & 0.236 & 4.56 & 6.19 & 0.283 & 0.754 \\
Treatment & 20 & $96.45^{* *}$ & $1606.29^{* *}$ & $237.18^{* *}$ & $9.47^{* *}$ & $8.05^{* *}$ & $27.66^{* *}$ & $2395.14^{* *}$ & $191.48^{* *}$ & $9.71^{* *}$ & $231.81^{* *}$ \\
Parent (P) & 5 & $81.55^{* *}$ & $2294.47^{* *}$ & $410.47^{* *}$ & 2.5 & $8.56^{* *}$ & $20.54^{* *}$ & $1940.67^{* *}$ & $221.26^{* *}$ & $6.65^{* *}$ & $67.93^{*}$ \\
Cross (C) & 14 & $86.98^{* *}$ & $1464.36^{* *}$ & $183.76^{* *}$ & $9.89^{* *}$ & $7.19^{* *}$ & $31.57^{* *}$ & $2387.9^{* *}$ & $139.36^{* *}$ & $11.33^{* *}$ & $249.9^{* *}$ \\
P vs C & 1 & $303.45^{* *}$ & $152.33^{*}$ & $118.62^{*}$ & $38.5^{* *}$ & $17.67^{* *}$ & $8.59^{*}$ & $4768.82^{* *}$ & $772.27^{* *}$ & $2.36^{*}$ & $35.13^{* *}$ \\
Error & 20 & 2.33 & 29.34 & 24.59 & 2.84 & 0.698 & 1.06 & 49.8 & 42.3 & 0.528 & 5.91 \\
\hline
\end{tabular}

*, ** significance level of probability at $5 \%$ and $1 \%$, respectively

Table 2. Statistic required for adequacy of simple additive dominance model

\begin{tabular}{|c|c|c|c|c|c|c|c|c|c|c|}
\hline $\begin{array}{c}\text { Paramet } \\
\text { er }\end{array}$ & $\begin{array}{l}\text { Days to } \\
\text { heading }\end{array}$ & $\begin{array}{c}\text { Plant } \\
\text { height }\end{array}$ & $\begin{array}{c}\begin{array}{c}\text { Flag leaf } \\
\text { area }\end{array} \\
\end{array}$ & $\begin{array}{l}\text { Leaf area } \\
\text { index }\end{array}$ & $\begin{array}{c}\text { Panicles/ } \\
\text { plant }\end{array}$ & $\begin{array}{c}\text { Panicle } \\
\text { length }\end{array}$ & $\begin{array}{c}\text { Filled grain/ } \\
\text { panicle }\end{array}$ & $\begin{array}{c}\% \text { spikelet } \\
\text { sterility }\end{array}$ & $\begin{array}{c}1000 \text { grain } \\
\text { weight }\end{array}$ & $\begin{array}{l}\text { Yield/ } \\
\text { plant }\end{array}$ \\
\hline $\mathrm{Vr}$ & 49.05 & 528.34 & 81.20 & 4.29 & 5.07 & 9.96 & 897.78 & 67.75 & 3.49 & 101.58 \\
\hline $\mathrm{Wr}$ & 29.38 & 483.38 & 74.03 & 0.80 & 2.95 & 7.84 & 591.81 & 44.19 & 2.53 & 16.96 \\
\hline$t_{(b=0)}$ & $3.33 *$ & $4.55^{*}$ & $6.09 * *$ & $3.36 *$ & $9.80 * *$ & $5.84 * *$ & $4.41 *$ & $3.29 *$ & $2.04^{\mathrm{ns}}$ & $0.24^{\mathrm{ns}}$ \\
\hline$t_{(b=1)}$ & $0.78^{\mathrm{ns}}$ & $0.34^{\mathrm{ns}}$ & $-0.39^{\mathrm{ns}}$ & $0.33^{\mathrm{ns}}$ & $0.81^{\mathrm{ns}}$ & $2.89 *$ & $2.58^{\mathrm{ns}}$ & $0.16^{\mathrm{ns}}$ & $2.04^{\mathrm{ns}}$ & $3.52 *$ \\
\hline $\mathrm{r}$ & 0.779 & -0.35 & -0.064 & -0.294 & -0.747 & 0.208 & $-0.842 *$ & 0.646 & 0.05 & 0.035 \\
\hline
\end{tabular}

$*$, ** significance level of probability at $5 \%$ and $1 \%$, respectively; $\mathrm{ns}=$ not significant

Regression coefficient $(b=0.685 \pm 0.291)$ for days to heading was neither significantly different from unity nor zero. However, elimination of array 1 for $\mathrm{P}_{1}$ gave a regression coefficient, $b=0.811 \pm 0.243$ (Fig.1a), which was significantly different from zero but not from unity, suggested additive genetic system and the parent $\mathrm{P}_{1}$ contained the epistatic genes. The regression line intercepted $\mathrm{Wr}$ axis below the origin $(\mathrm{a}=-10.39)$ indicating overdominance gene action for the trait. In the $\mathrm{Wr}-\mathrm{Vr}$ graph, $\mathrm{P}_{2}$ occupied the closest position to the point of origin indicating preponderance of dominant gene, while $\mathrm{P}_{4}$ possessed the farthest from the origin followed by $\mathrm{P}_{6}$ suggested recessive gene action for expressing the trait. The parents $\mathrm{P}_{3}$ and $\mathrm{P}_{5}$ were at the intermediate position in the $\mathrm{Wr}-\mathrm{Vr}$ graph indicating almost equal control of dominant and recessive gene. The $\mathrm{Y}^{\prime}-(\mathrm{Vr}+\mathrm{Wr})^{\prime}$ graph (Fig.1b) suggested similar predominance of dominant alleles in $\mathrm{P}_{2}$ with positive effect and recessive 
alleles in $\mathrm{P}_{4}$ with negative effect. However, the positive correlation $(\mathrm{r}=0.779)$ between parental mean and parental order of dominance revealed decreasing effect of dominant gene i.e. early heading was apparently dominant over late heading.

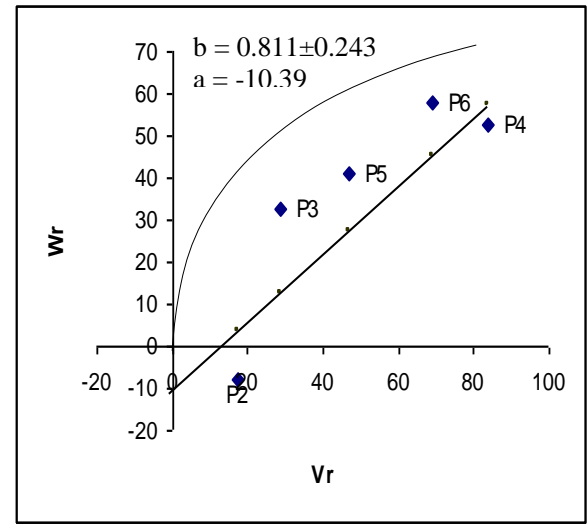

Fig.1a. Wr-Vr graph for days to heading ( array 1

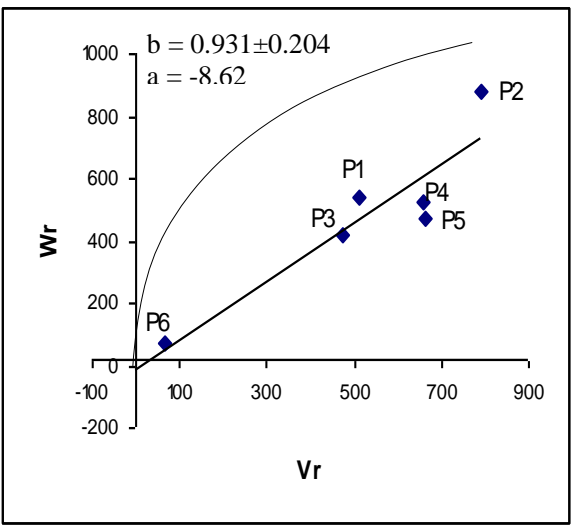

Fig.2a. Wr-Vr graph for plant

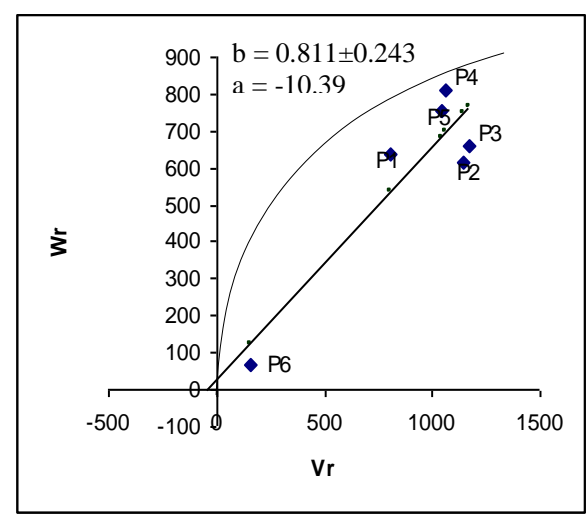

Fig. 3a. Wr-Vr graph for flag leaf area

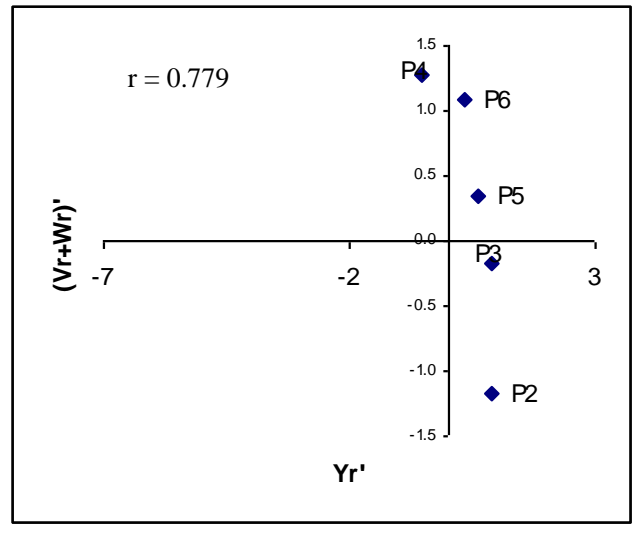

Fig.1b. $\mathrm{Yr}^{\prime}-(\mathrm{Vr}+\mathrm{Wr})^{\prime}$ graph for days to

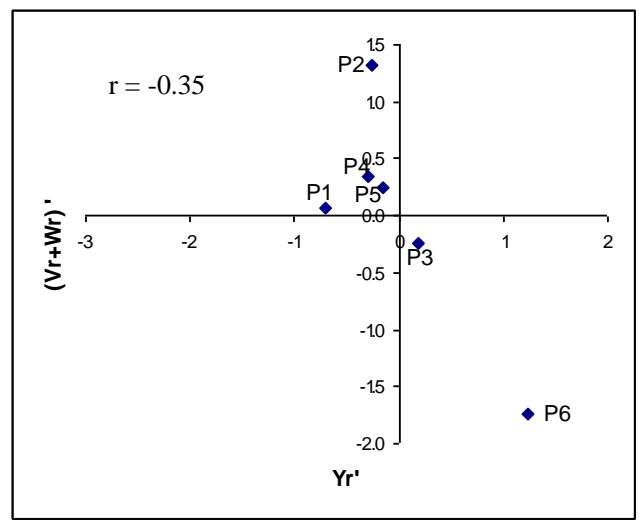

Fig. 2b. $\mathrm{Yr}^{\prime}-(\mathrm{Vr}+\mathrm{Wr})^{\prime}$ graph for

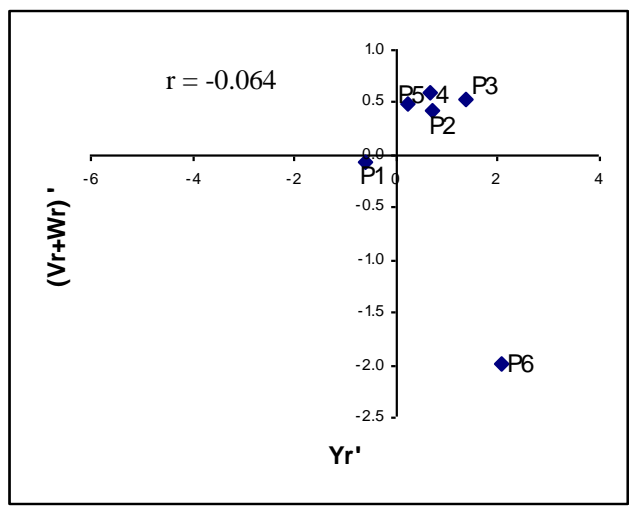

Fig. 3b. $\mathrm{Yr}^{\prime}-(\mathrm{Vr}+\mathrm{Wr})^{\prime}$ graph for flag leaf 


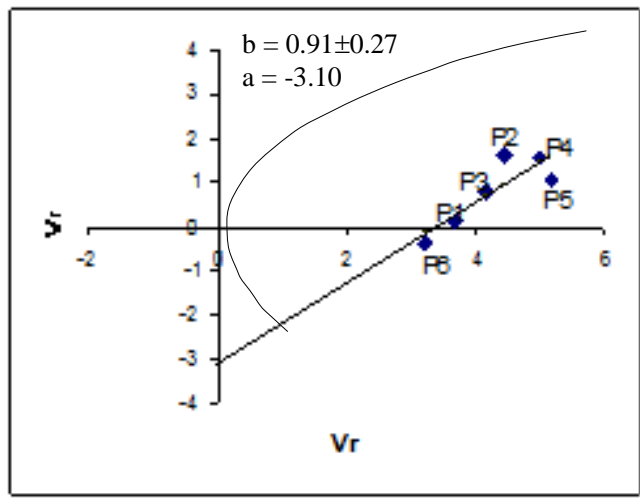

Fig. 4a. Wr-Vr graph for leaf area index

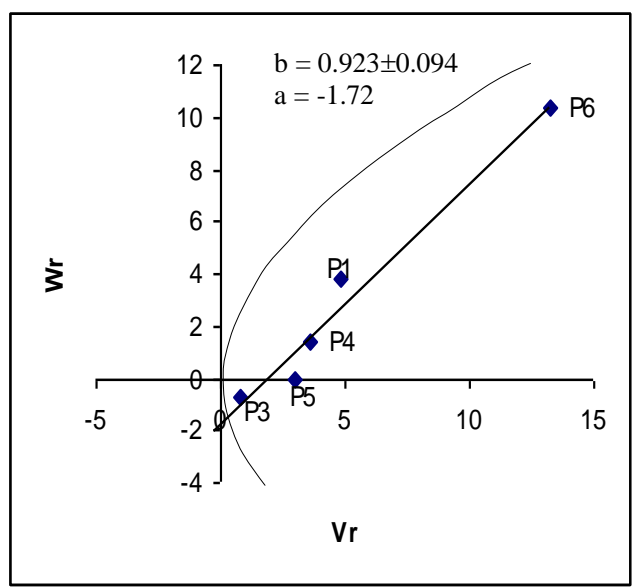

Fig.5a. Wr-Vr graph for panicles/plant

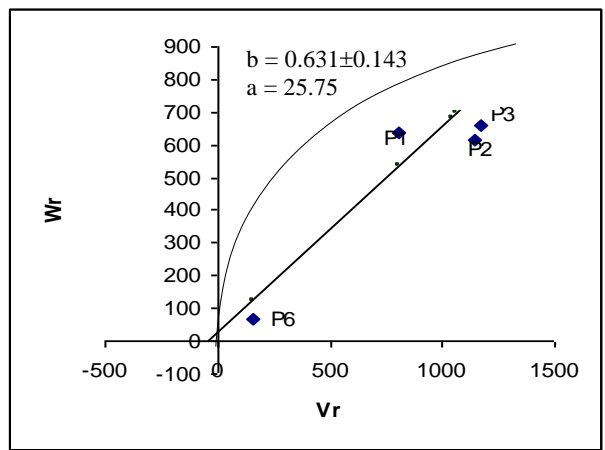

Fig.6a. Wr-Vr graph for filled grains/panicle

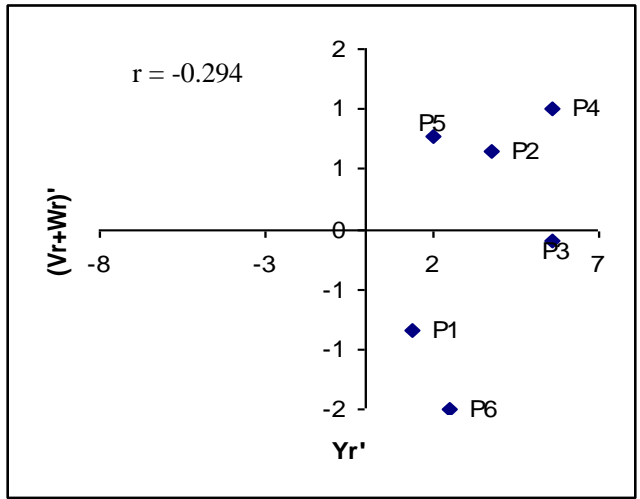

Fig.4b. $\mathrm{Yr}^{\prime}-(\mathrm{Vr}+\mathrm{Wr})^{\prime}$ graph for leaf area

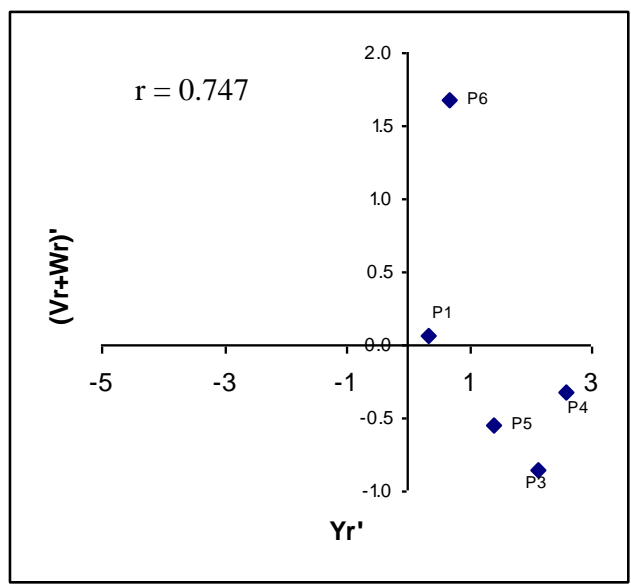

Fig.5b. $\mathrm{Yr}^{\prime}-(\mathrm{Vr}+\mathrm{Wr})^{\prime}$ graph for panicles/plant

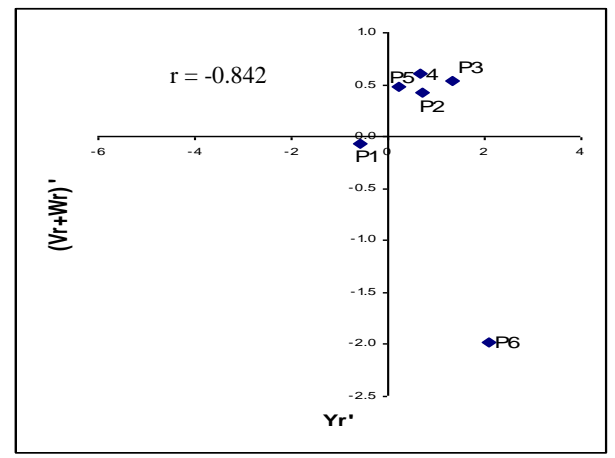

Fig.6b. $\mathrm{Yr}^{\prime}-(\mathrm{Vr}+\mathrm{Wr})^{\prime}$ graph for filled grains/panicle 


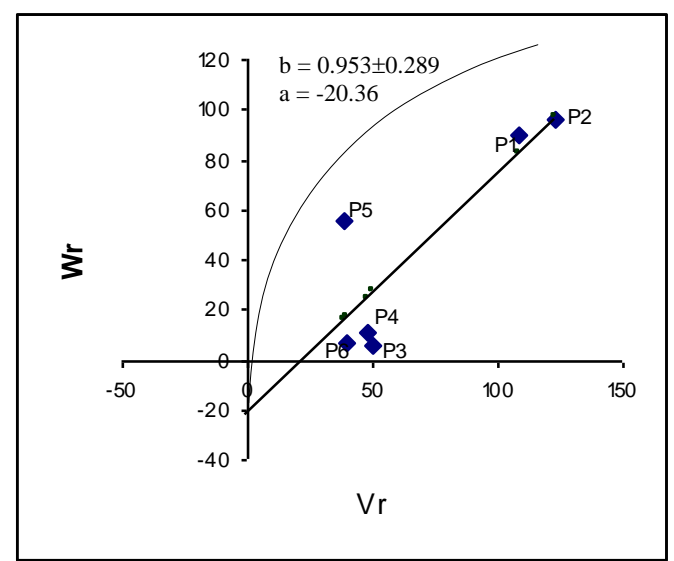

Fig.7a. Wr-Vr graph for \% spikelet sterility

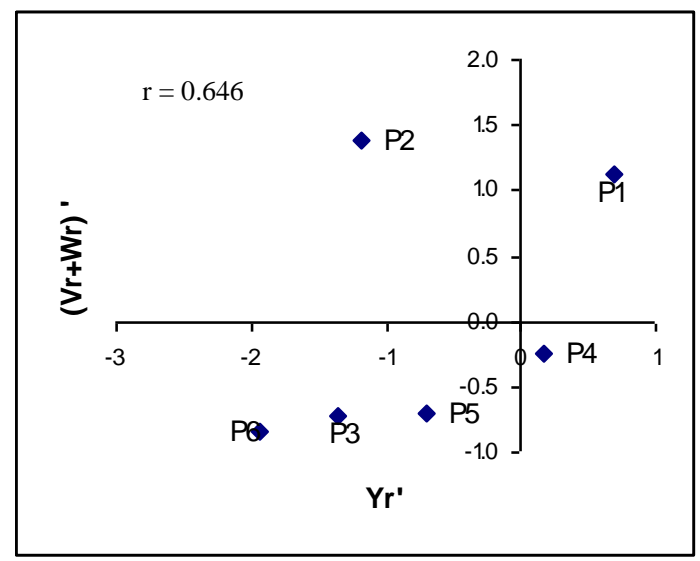

Fig.7b. $\mathrm{Yr}^{\prime}-(\mathrm{Vr}+\mathrm{Wr})^{\prime}$ for \% spikelet sterility

The simple additive dominance model was found adequate as the regression coefficient $(b=0.931 \pm 0.204)$ for plant height was significantly different from zero but not from unity. In $\mathrm{Wr}-\mathrm{Vr}$ graph (Fig.2a), the regression line intercepted $\mathrm{Wr}$ axis below the origin at -8.62 , indicating overdominance gene action for the trait. The relative distribution of array points in graph showed that P6 occupied the closest and P2 the farthest position from the origin, while other parents occupied more or less intermediate position. These indicated that $\mathrm{P}_{6}$ and $\mathrm{P}_{2}$ possessed maximum frequency of dominant and recessive alleles, respectively, while other parents were conditioned by almost equal frequencies of dominant and recessive alleles. The array points in $\mathrm{Y}^{\prime}-(\mathrm{Vr}+\mathrm{Wr})^{\prime}$ graph (Fig. 2b) also indicated preponderance of dominant alleles with positive effect in $\mathrm{P}_{6}$ and recessive alleles with negative effect in $\mathrm{P}_{2}$. Furthermore, the correlation coefficient $(\mathrm{r}=-0.35)$ between $\mathrm{Yr}^{\prime}$ and $(\mathrm{Vr}+\mathrm{Wr})^{\prime}$ was negative indicating increasing effect of dominant gene i.e. longer plant height was barely dominant over shorter plant height.

The Wr-Vr graph for flag leaf area is shown in Fig. 3a. The analysis of all arrays showed a regression coefficient $(b=1.068 \pm 0.75)$ significantly different from zero but not from unity, which indicated that the data was adequately fit for additive dominance model. The regression line in $\mathrm{Wr}-\mathrm{Vr}$ graph intercepted $\mathrm{Wr}$ axis below the origin $(\mathrm{a}=-12.74)$ indicating overdominance gene action for the tarit. Occupying the nearest and furthest position to and from the origin in $\mathrm{Wr}-\mathrm{Vr}$ graph $\mathrm{P}_{3}$ and $\mathrm{P}_{1}$ were highly influenced by dominant and recessive alleles, respectively. The $\mathrm{Yr}^{\prime}-(\mathrm{Vr}+\mathrm{Wr})^{\prime}$ graph (Fig.3b) also confirmed the above findings.

The analysis of all arrays for leaf area index was found adequate for simple additive dominance model as the regression coefficient $(b=1.068 \pm 0.75)$ differed significantly from zero but not from unity. The regression line intercepted $\mathrm{Wr}$ axis in $\mathrm{Wr}-\mathrm{Vr}$ graph (Fig.4a) below the origin $(a=-3.10)$ indicating overdominance gene action for this trait. The relative position of the array points of respective parents suggested predominance of dominant alleles in $\mathrm{P}_{6}$ and recessive alleles in $\mathrm{P}_{4}$, while $\mathrm{P}_{3}$ was conditioned equally by dominant and recessive alleles. The $\mathrm{Yr}^{\prime}-(\mathrm{Vr}+\mathrm{Wr})^{\prime}$ graph (Fig. $\left.4 \mathrm{~b}\right)$ also confirmed the reults of above findings. The non-significant negative correlation $(\mathrm{r}=-0.294)$ between $\mathrm{Yr}^{\prime}$ and $(\mathrm{Vr}+\mathrm{Wr})^{\prime}$ indicated that higher leaf area index was barely dominant over lower leaf area index. 
In case of panicles per plant, the regression coefficient $(b=0.654 \pm 0.266)$ for all arrays was neither significantly different from unity nor zero. However, elimination of array $2\left(\mathrm{P}_{2}\right)$ from the analysis gave a regression coefficient, $\mathrm{b}=0.923 \pm 0.094$ (Fig. 5a) significantly different from zero but not from unity. This suggested that the parent $\mathrm{P}_{2}$ contained some sorts of the epistatic genes and the trait appeared to be conditioned by additive-dominance gene action. The regression line passed below the origin intercepting $\mathrm{Wr}$ axis at -1.72 , which indicated overdominance gene action for the expression of panicles per plant. The $\mathrm{Wr}-\mathrm{Vr}$ graph showed that $\mathrm{P}_{3}$ was closest and $\mathrm{P}_{6}$ was farthest from the origin, which implied preponderance of dominant alleles in $\mathrm{P}_{3}$ and recessive alleles in $\mathrm{P}_{6}$ for expressing this trait. The $\mathrm{Y}^{\prime}-(\mathrm{Vr}+\mathrm{Wr})^{\prime}$ graph (Fig. 5b) also confirmed the above findings. The negative correlation $(r=-0.747)$ between parental mean and parental order of dominance revealed increasing gene action, i.e. higher number of panicles per plant was dominant over lower number.

The regression coefficient $(b=0.631 \pm 0.143)$ for filled grains per panicle was significantly different from zero but not from unity. This revealed the adequacy of simple additive dominance model. In the $\mathrm{Wr}-\mathrm{Vr}$ graph (Fig. 6a), the regression line intercepted $\mathrm{Wr}$ axis at 25.75 indicating partial dominance gene action for the trait. The relative position of array points for respective parent in the graph showed that $\mathrm{P}_{6}$ was the closest to the origin and other parents were the farthest from the origin occupying a cluster. These indicated that $\mathrm{P}_{6}$ possessed maximum frequency of dominant, where as recessive alleles were predominant in the rest five parents for this trait. The $\mathrm{Y}^{\prime}-(\mathrm{Vr}+\mathrm{Wr})^{\prime}$ graph (Fig. 6b) also revealed preponderance of dominant alleles with positive effect in P6 and recessive alleles with more or less equal positive and negative effect in other parents. Furthermore, the correlation coefficient $(\mathrm{r}=-0.842)$ between $\mathrm{Yr}^{\prime}$ and $(\mathrm{Vr}+\mathrm{Wr})^{\prime}$ was negative indicating increasing effect of dominant genes for filled grains per panicle. The regression coefficient for spikelet sterility was also significantly different from zero but not from unity, i.e. the data was adequate for simple additive dominance model. The regression line in $\mathrm{Wr}-\mathrm{Vr}$ graph (Fig. 7a) intercepted $\mathrm{Wr}$ axis at -20.36 , indicating overdominance gene action for the character. The relative position of array points indicated that $\mathrm{P}_{6}, \mathrm{P}_{4}$ and $\mathrm{P}_{3}$ possessed maximum frequency of dominant and $\mathrm{P}_{1}$ and $\mathrm{P}_{2}$ were predominated with recessive alleles, while $\mathrm{P}_{5}$ was conditioned by equal frequencies of dominant and recessive alleles for this trait. The $\mathrm{Y}^{\prime}$ - $(\mathrm{Vr}$ $+\mathrm{Wr})^{\prime}$ graph (Fig. 7b) also revealed preponderance of dominant alleles in $\mathrm{P}_{6}, \mathrm{P}_{4}$ and $\mathrm{P}_{3}$ and recessive alleles in $\mathrm{P}_{1}$ and $\mathrm{P}_{2}$. The correlation coefficient $(0.646)$ between $\mathrm{Yr}^{\prime}$ and $(\mathrm{Vr}+\mathrm{Wr})^{\prime}$ was positive indicating decreasing effect of dominant gene for spikelet sterility.

\section{REFERENCES}

Dhabolkar, A. R. 1992. Elements of Biometrical Genetics. Concept Publishing Company, New Delhi, India. $\mathrm{p} 431$.

Hayman, B. I. 1954. The theory and analysis of diallel crosses. Genetics 39: 789-809.

Iftekharuddaulla, K. M. 2003. Genetic analysis of morpho-physiological characters in diallel cross of rice. MS thesis. Bangladesh Agricultural University. Mymensingh.

Johnson, L. P. V and R.Askel.1959. Inheritance of yielding capacity in a fifteen parent diallel cross of barley. Canadian J. Genet. Cytol. 1: 208-265.

Mather, K. and J. L. Jinks. 1949. Biometrical Genetics: The study of continuous variation. Chapman and Hill, London. U.K. p 396.

Sharma, J. R. 1998. Statistical and Biometrical Techniques in Plant Breeding. New Age International (P) Limited, New Delhi, India. p 432. 